\title{
FEATURES OF FUTURE PHYSICAL EDUCATION SPECIALISTS' PERSONALITY'S ACME-TRAITS DEVELOPMENT
}

\section{Dereka Tetiana ${ }^{1}$ \\ Iskra Ulyana ${ }^{2}$}

DOI: dx.doi.org/10.30525/978-9934-571-30-5_27

Abstract. There is a process of physical education specialists' personality's acme-traits development and forming during the acmeologically based lifelong vocational training explored in the article. The selection and modification of several methods carried out was done in the research, such as: test-questionnaire "Personality maturity"; questionnaire "Method of organizational ability assessment"; test "Determining of communicative abilities"; diagnosis of "Emotional intelligence" after N. Hall (following scales: emotional awareness, emotional control, empathy, recognition of other people's emotions); method "Self-assessment of person's creative potential". There were 194 students of "Physical education" specialty involved in the study. The control (98 people) and the main (96 persons) group of students were formed for the pedagogical experiment purposes. The control and experimental groups were homogeneous $\left(\mathrm{V}_{\mathrm{c}}=17,3 \% ; \mathrm{V}_{\mathrm{e}}=18,5 \%\right)$ at the beginning of the experiment. We used following standard methods of statistical data processing to analyse results of the study: the method of averages, the calculation of the Student's t-criterion, correlation and factor analysis. The interconnections of the acmeological competence components indicators were proved experimentally as a result of factor analysis such as: acme-motivation, cognitive-acmeological, acmeological-activity, personality's acme-traits (acme-motivational and personal, personal and professional, emotional and psychological, cognitive-acmeological and research). The biggest factor weight had the motivation of achievement $(0,83)$, the ability to psychological proximity to other person $(0,8)$, the attitude to them-

\footnotetext{
${ }^{1}$ Doctor of Sciences in Education, Associate Professor,

Professor of Theory and Methods of Physical Culture Department,

Makarenko Sumy State Pedagogical University, Ukraine

${ }^{2} \mathrm{PhD}$ in Physical Education and Sports,

Lecturer of Physical Education and Sports Pedagogy Department, Faculty of Health, Physical Training and Sports,

Borys Grinchenko Kyiv University, Ukraine
} 
self ("Self-concept") (0.79), empathy (0.77), educational-cognitive motives $(0,74)$, motives of prestige $(0,71)$, professional motives $(0,70)$. The personality's acme-traits were grouped according to the strength of intercorrelation as a result of the correlation analysis. Strong correlation with the level of personality's acme-traits development had following indexes: creativity of students $(\mathrm{r}=0,91)$ and their communicative skills $(\mathrm{r}=0,91)$, as well as organizational ability $(r=0,89)$, need of achievements $(r=0,76)$, the attitude to themself ("Self-concept") $(r=0,74)$ and the ability to psychological proximity to other person $(r=0,74)$. Significant correlation on the level of physical education specialists' acmeological competence develpopment had such acme-traits of personality as: sense of civic duty $(r=0,65)$, empathy $(\mathrm{r}=0,64)$, ability to recognize the emotions of others people $(r=0,6)$ and emotional awareness $(r=0,53)$. Acme-trait of personality as management of emotions had a moderate influence on the level of physical education specialists' acmeological competence development $(r=0,44)$ as it was showed by correlation analysis. The level of personality's acme-traits development as a component of the physical education specialists' acmeological competence in the process of continuing vocational training based on acmeology for the experimental group of students was $73,9 \%$. This indicator was $54,68 \%$ in the control group, that is $19,22 \%$ less than for the experimental group. Prospects for further research are the acmeological approach application to the training of specialists in physical education at the $\mathrm{PhD}$ level.

\section{Introduction}

Professional training of physical education specialists is increasingly aimed at achieving high professional qualifications, the ability to continuous development and compliance with modern requirements. The main characteristics of the modern physical education specialists professional training are the value attitude to the health, the need to implement the state strategy for the development of the young people physical education system, forming the responsible attitude to their own health and to a healthy lifestyle, creating conditions for complete physical and moral development.

The problem of professional forming and development of the person, its self-improvement is the key one for such a branch of science as acmeology. That is why professional training of physical education specialists should be aimed at the forming, development and implementation of individual acmetraits, stimulating and promoting the achievements of the highest level of 
professional and personal acme in the conditions of increased competition on the modern labor market.

According to N. Kuzmina, modern acmeology is a branch of scientific knowledge, a complex of scientific disciplines, which object of study is a person in the dynamics of self-actualization of its creative potential, self-development, self-improvement, self-determination in various spheres of life, independent professional activity, system of improvement qualifications [7, p. 18]. The researcher notes that an important component of acmeological competence is personality's acme-qualities which provide a man the movement to the intended achievements. According to scientists, if the akmeological approach is applied then the leading role will be played by the problems of professionals' creative abilities development taking into account various aspects of their preparation and improvement [1, p. 6-7].

O. E. Antonova determined the factors contributing to the development of pedagogical talent and the pedagogical mastership forming (on the examples of Y. A. Komensky, K. D. Ushinsky, A. S. Makarenko) using the biographical method of distinguishing the qualities of a talanted teacher [2, p. 24]: a favorable educational environment; thorough high education; conscious choice of the teaching profession; wide horizons, encyclopedic knowledge; workability, perseverance; desire of self-education; creativity; the ability to start everything from the beginning, to overcome difficulties, the power of will; influence of strong personalities; oratory gift; literary gift; love for children.

Researchers note that the modern teacher of physical education should possess following personality's traits [9, p. 93]: the desire for self-education, love for children, reasonable demands, sense of measure, pedagogical tact, personal example, ability to control their activity and behavior, observancy, ingenuity, ability to use voice, facial expression, gesture, pedagogical intuition.

A physical education specialist has an important task to fulfill nowadays. It is to promote a harmoniously developed personality's forming. Therefore, in our opinion, the teacher should have such professionally important personality's acme-traits: well developed integral mental capacities of the personality (such as attention, memory, thinking), mental characteristics (emotional warmth, patience), personal and professional qualities (organization, communicative, responsible, discipline, initiative, creativity), volitional qualities as a personality will [5, p. 58]. 
According to V. D. Gladkov, it is important to take into account the acmeological invariants of professionalism - the main properties, qualities and skills of a professional, providing high efficiency and stability of the activity, regardless of its content and specificity [3, p. 18]. A. A. Derkach's studies state that the concept of professional acmeological invariants makes it possible to significantly accelerate the processes of individual and professional development of a specialist [6, p. 143].

However, the process of physical education specialists personality's acme-traits forming while their vocational training based on the acmeology researchers has not been studied.

So the aim of the research was to investigate the process of physical education specialists personality's acme-traits forming in the process of acmeologically based continuous vocational training.

So tasks of the research were:

1. To find out the peculiarities of the physical education specialists personality's acme-trait in the process of continuous vocational training based on the acmeology principles.

2. To substantiate the interinfluence and interdependence of personality's acme-traits as a component of physical education specialist's acmeological competence.

3 . To study the peculiarities of the physical education specialists' acmetraits forming in the process of continuous vocational training based on the acmeology.

\section{Research methods}

There were 194 students learning for the bachelor degree in "Physical education" involved in the study. There were two groups formed for the pedagogical experiment - control group $(n=98)$ and experimental group $(n=96)$. The control and the experimental groups were homogeneous at the beginning of the experiment (variation indexes were for the control group $\mathrm{V}_{\mathrm{c}}=17,3 \%$; for the experiment $\mathrm{V}_{\mathrm{e}}=18,5 \%$ ). The difference between the control and the experimental groups was statistically not reliable $(p>0,05)$ at the beginning of the experiment. The selection and modification of several methods carried out was done in the research, such as: test-questionnaire "Personality maturity"; questionnaire "Method of organizational ability assessment"; test "Determining of communicative abilities"; diagnosis of "Emotional intelligence" after N. Hall (following scales: emotional aware- 
ness, emotional control, empathy, recognition of other people's emotions); method "Self-assessment of person's creative potential". The research was conducted in Boris Grinchenko Kyiv University during 2009-2016.

We used following standard methods of statistical data processing to analyse results of the study: the method of averages, the calculation of the Student's t-criterion, correlation and factor analysis. There was the statistic software "Statistica" [8] used to analyze results of the pedagogical experiment.

\section{Conceptual idea of continuous professional training}

The leading conceptual idea of physical education specialists' continuous professional training based on the principles of acmeology is the thesis that if the specialists' professional training involves the forming of motivation and the ability to achieve the acme by implementing his own professional acme and personal traits then his continuous professional and personal development, self-development and self-improvement of the physical education specialist will continue during the whole life and professional activity in the conditions of a globalized world, the integration and informatization of modern education systems.

We made an assumption that if the specialist has an acmeological competence formed in the process of continuous professional training at a higher educational institution, he will be able to continue solving professional problems of various levels of complexity, lifelong education, self-development and self-improvement [4, p. 53; 11, pp. 99-102].

The author's concept of continuous professional training of physical education specialists on the principles of acmeology is realized in the process of learning in the higher educational institution and is aimed at the acmeological competence forming at all levels of higher physical education. The accents differed in the acmeological competence forming in the process of physical education specialists' continuous professional training on the principles of acmeology. Accents shifted from the initial level of higher education to the bachelor's and master's levels.

At the initial level of higher education, the acme-motivational component of acmeological competence is predominantly formed by specialists in physical education as a set of motivations and conditions that determine, activate, direct and regulate acme-oriented self-development of a specialist.

At the undergraduate level of higher education students, the emphasis is 
shifted to the forming of the cognitive-acmeological component of acmeological competence during the study of the disciplines of the humanities, socio-economic, natural sciences, professional and practical training cycles.

At the master's level of higher education, professional training focuses on the forming of acmeological-activity components of acmeological competence in the process of students' independent work and researches.

There are personality's acme-traits being improved at all levels of education in the process of physical education specialists' continuous professional training based on the acmeology principles. And this acme-traits contribute to the personality's activity manifestation in the professional development process and also constant self-development and self-development as a specialist [5, p. 58].

The result of physical education specialists'continuous professional training on the acmeology basis is a graduatee's acmeological competence formed, as an integrated quality that provides the ability and acme-motivation of the individual to continuous learning, self-improvement, self-development throughout life [10, pp. 59-62].

\section{Interconnection of components of acmeological competence}

We compared results of the pedagogical experiment obtained for the experimental and the control groups by using cluster analysis. The biggest difference obtained between the levels of acmeological competence (Var2) and its components for the students of the control and experimental groups. There was the acme-motivational component (Var3) of the physical education specialists' acmeological competence obtained to be the most labile as a result of the cluster analysis application. So affecting this component, especially in the initial and first and second bachelor levels of higher education, we can activate and direct acme-oriented self-development of physical education specialist (Fig. 1).

To verify the author's concept of physical education specialists' continuous professional training based on the acmeology principles, we used a factor analysis. As a result of factor analysis, there were following interconnections of the indicators of acmeological competence components proved experimentally: acme-motivation, cognitive-acmeological, acmeological-activity, personality's acme-traits (acme-motivational and personal, personal and professional, emotional and psychological, cognitive-acmeological and research) (Fig. 2). 


\section{Dereka Tetiana, Iskra Ulyana}

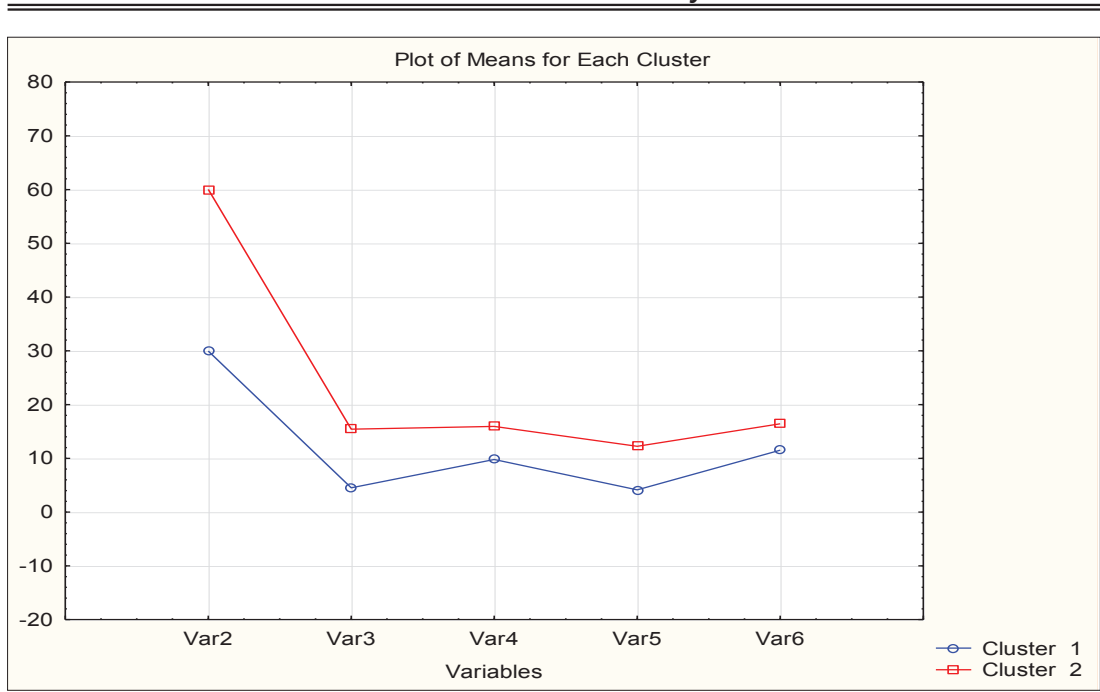

Fig. 1. Cluster analysis results of the physical education specialists' acmeological competence level its components

Var2 - specialists' acmeological competence; Var3 - acme-motivational component; Var4 - cognitive-acmeological component; Var5 - acmeological-activity component; Var6 - acme-traits of personality; Cluster 1 is a control group of students; Cluster 1 is an experimental group of students.

Consequently, components of acmeological competence (acme-motivation, cognitive-acmeological, acmeological-activity and acme-quality personality) are formed, developed, improved, being in mutual communication, and affect each other.

The indicators of the acme-motivational and personal factors (1) were following: the motives of prestige, professional motives, educational and cognitive motives, the motivation of achievement, and the components of the personal component: the attitude to himself ("Self-concept"), the ability to psychological proximity to another person, empathy.

Indicators of the personal and professional factors (2) were following: organizational skills, communicative abilities, the need of achievement, creative potential of the individual, social motives.

Indicators of emotional and psychological factors (3) were following: self-motivation, emotional awareness, other persons' emotions recognition (diagnosis of "Emotional intelligence"). 


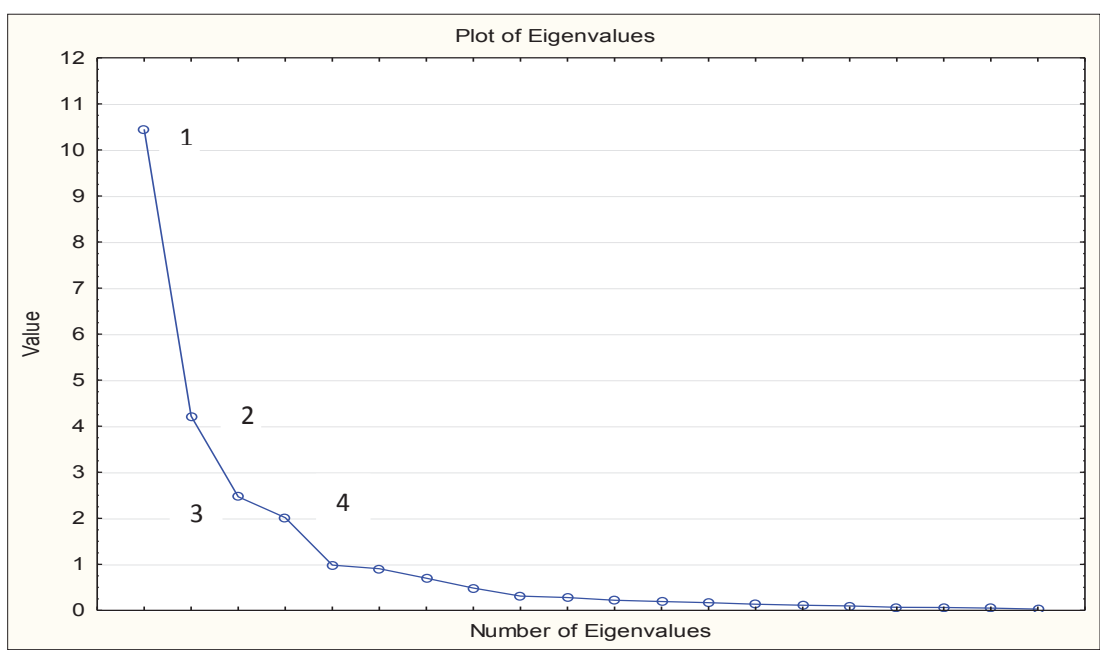

Fig. 2. Indicators of factor analysis of the grouping of indicators of physical education specialists' acmeological competence components: acme-motivational and personal (1), personal and professional (2), emotional and psychological (3), cognitive-acmeological and research (4).

The indicators of the cognitive-acmeological and research factor (4) were following: the results of research work of students, the integral indicator of the motivation of activity.

This four selected factors covered $79,8 \%$ of all indicators of acmeological competence components. Thus, the accumulated percentage of the dispersion of the four factors indicates that we sufficiently fully describe our obtained data by applying the factor analysis. The total percentage of dispersion for each factor indicates its significance. The most significant factor obtained in our research is the acme-motivational and personality factor, which has the highest percentage of total dispersion of 43,53\%. Acme-motivational and personal factor includes the most variables (constituent components of acmeological competence). Let us analyze the quantitative values the first factor objects with the help of the "factor scores" indicator. The greatest factor weight has the motivation of achievement $(0,83)$, the ability to psychological proximity to another person $(0,80)$, the attitude to themself ("Self-concept") $(0,79)$, empathy $(0,77)$, educational-cognitive motives $(0,74)$, motives of prestige $(0,71)$, professional motives $(0,70)$. 
These indications also have a high correlation within the acme-motivational component and acme-traits of personality.

Acme-traits of personality, which according to the cluster analysis is not very labile, but can be improved at all educational levels and facilitate an activity in individual life long learning, self-development and self-improvement of physical education specialist.

The personal and professional factor makes $17,6 \%$ of the total dispersion, which indicates its sufficient significance. The biggest factor weight with social motives $(0,68)$, the need for achievement $(0,57)$, communication skills $(0,56)$, organizational skills $(0,55)$, creativity identity $(0,48)$.

These acme-traits of personality have a high rate of correlation coefficient, which indicates a strong link with the result, the level of physical education specialists' acmeological competence level.

Acme-traits of personality is the basis for the professional development of a specialist in the process of studying at a higher educational institution and contributes to its self-development, self-improvement throughout life.

Emotional and psychological factor makes $10,3 \%$ of the total variance, indicating the importance of professionally important qualities of mental properties of the individual teacher, psychological characteristics (emotional warmth, patience) personal and professional skills (organization, communicative, responsibility, discipline, initiative) in professional activities, the result of which is the forming of a harmoniously developed personality of pupils and students. The greatest factor weight is the recognition of other people emotions $(0,7)$, emotional awareness $(0,6)$ and self-motivation $(0,5)$.

\section{Correlation analysis of personality's acme-traits forming}

Akme-traits of personality can be improved at all levels of education in the continuous process of physical education specialists' professional training based on the acmeology principles. Its contribute to the manifestation of personality activity in the process of learning, self-development, self-improvement, achievement of personal and professional acme.

Acme-traits of personality as a component of the physical education specialists' acmeological competence forming indicators are presented on Figure 3.

Acme-traits of the personality as an acmeological competence component we researched analyzing the level of physical education students following acme-traits: organizational skills, communicative abilities, cre- 


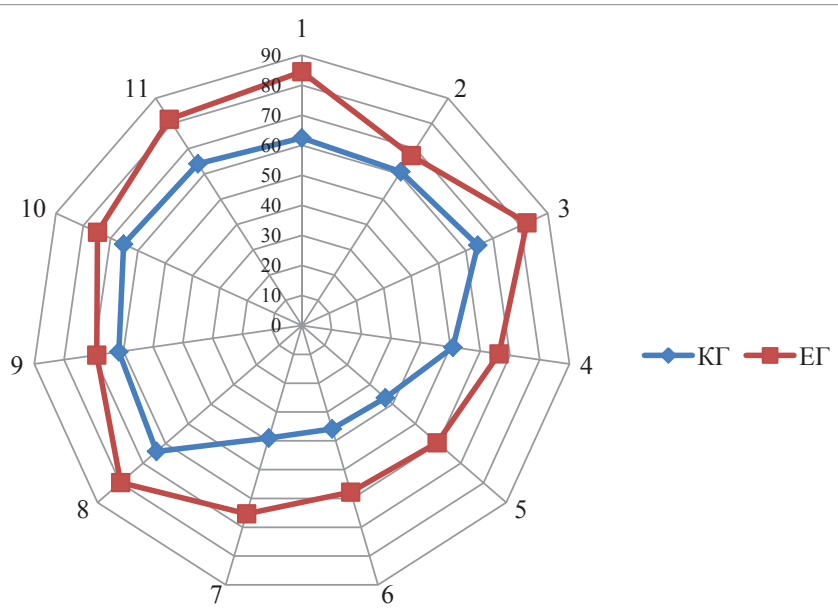

Fig. 3. Model of the acme-traits of personality as a component of the physical education specialists' acmeological competence forming indicators

1 - the attitude to himself ("Self-concept"); 2 - a sense of civic duty; 3 - the ability to psychological proximity to other person; 4 - organizational abilities; 5 - communicative abilities; 6 - creative potential (creativity); 7 - the need of achievements; 8 - emotional awareness; 9 -managing emotions; 10 - empathy; 11 -recognition of other people emotions.

ative potential (creativity), the need for achievement, emotional awareness, emotional management, empathy, psychological ability proximity to another person, recognition of emotions of other people, attitude to himself ("Self-concept"), a sense of civic duty.

As a result of the cluster analysis, we revealed that the level of acmetraits of personality is the most stable component of the physical education specialists'acmeological competence. Therefore, acme-traits of personality is mostly inherited from parents, their forming takes time, so they are improved at all levels of education and throughout life, as a result of self-development and self-improvement.

Forming of acme-traits of personality as a component of physical education specialists' acmeological competence is going unevenly during the learning in a higher educational institution, and its indices have a different influence on the final level. 
As a result of the correlation analysis, we revealed the strength and direction of mutual influence of acme-traits as a component of physical education specialists' acmeological competence. We grouped acme-traits of personality in accordance to the strength of the correlation relationship.

Thus, a high correlation with the level of acme-traits of personality forming has creativity of students $(\mathrm{r}=0,91)$ and communicative skills $(\mathrm{r}=$ $0,91)$, as well as organizational abilities $(r=0,89)$.

Creativity level as a systemic trait of intelligence, a set of features of the human psyche that ensures the implementation of his own individuality was $57,8 \%$ for students of experimental group in the end of study at the master's level of high education. In the control group, the figure was $35,86 \%$, which is $21,9 \%$ less than for the experimental group.

Such important traits for the professional activity of physical education specialists as communicative abilities, ability to communicate with colleagues and parents or students, the ability to find the right approach to them, the ability to predict the result of pedagogical action, were formed on $59,6 \%$ in the experimental group during the process of vocational training. This indicator was $36,76 \%$ for the control group, that is $22,8 \%$ lower then for experimental group.

The index of organizational abilities (as an ability to organize the activities of the team and optimize their own activities (to plan and control)) for students of the experimental group in the process of continuous vocational training on the acmeology basis of was $66.3 \%$. At the same time, in the control group the level of organizational skills was $50,79 \%$, which is $15,5 \%$ less than result for the experimental group of students.

The next group of personality acme-traits, which according to the correlation analysis results have a high correlation with the level of acmeology competence component are: the need of achievement $(\mathrm{r}=0,76)$, the attitude to himself ("Self-concept") $(r=0,74)$ and the ability to psychological proximity to another person $(\mathrm{r}=0,74)$.

The need of achievements as one of the main acme-traits of the individual, especially for physical education students, the desire to surpass the already achieved level of performance, a competition with himself or with others is a basis of persistence in obstacles overcoming. For experimental group students the need for achievements was formed on the $65,3 \%$ in the process of continuing vocational training based on the acmeology principles. For the students of the control group the figure was $39.1 \%$ during the 


\section{Chapter 13. Pedagogical sciences}

corresponding period of study, which is $26.25 \%$ less than for the experimental group.

"Self-concept", which includes awareness of their physical and intellectual natural traits, self-esteem and subjective perception, which characterizes the influence on the own personality of external factors for experimental group students was $84,5 \%$ in the process of continuous vocational training on the acmeology basis. In the control group, the level of the attitude towards their Self was $62,46 \%$ which was $22,04 \%$ lower.

Ability to psychological proximity to another person, the ability of listening, the need for moral proximity are important for people who chose the occupation of "man-to-man" type. The level of this component of personality's acme-traits as a component of acmeological competence for experimental group students was $82,4 \%$. The students of the control group for this indicator had $64,36 \%$, which was $18 \%$ less than the main group.

As a result of the correlation analysis, we have identified a group of personality's acme-traits which have a significant correlation and interact with the level of this acmeological competence component for physical education specialists.

Therefore, a significant correlation with the level of personality's acmetraits has a sense of civic duty $(r=0,65)$, empathy $(r=0,64)$, ability to recognize emotions of other people $(\mathrm{r}=0,6)$ and emotional awareness $(\mathrm{r}=0,53)$.

The sense of civic duty associated with such personal traits as patriotism, interest in the phenomena of social and political life, a sense of professional responsibility, the need for communication and collectivism at the present stage of Ukrainian society development is a prerequisite for the forming of a competent, competitive modern teacher, who is able to bring up a young generation of Ukrainians. The level of a sense of civic duty as an integral part of personality's acme-traits as a acmeological competence component for students experimental group was $67,3 \%$. For the control group students, the figure is $60,9 \%$, which was $6,4 \%$ less than the main group. In our opinion, the contradictions that currently exist in the country social and political life, have controversial and not very positive impact on this trait development for students.

Empathy as an ability to empathize, to feel and understand feelings of other person, the need for selfless creation of favorable conditions for person's in need of support positive emotional state and vital activity, is an important personality's acme-trait and not only for physical education 
specialists, but also is one of indicators of a high level of humanistic component development and the moral of society as a whole. The experimental group students in the process of continuous acmeology based vocational training the level of empathy as a personality's acme-trait index was $74,8 \%$. For the control group students this indicator was $65,21 \%$, which is $9,59 \%$ lower than for the experimental group.

Recognizing the emotions of other people is an indicator of the "emotional intelligence" of the individual which shows the person's ability to control the collocutor's emotional status and feelings, to feel and recognize the emotional component of interpersonal relationships. It is important to develop this personality's acme-trait as a component of acmeological competence in the occupation of "man-to-man" type such as educator. The experimental group students' level of this trait was $81,65 \%$ in the process of acmeology based continuous vocational training. In the control group this trait development was $64 \%$ that was $17,65 \%$ less.

Emotional awareness reflects the level of human understanding of the content of normalities and phenomena of affective life, an understanding of what emotional reaction can cause any event, word or doing. In the experimental group, the level of emotional awareness was $79,8 \%$, which was $15,77 \%$ more than in the control group, in which the figure was $64 \%$.

Management of emotions as a personality's acme-trait has a moderate correlation with the level of this physical education specialists' component of acmeological competence $(\mathrm{r}=0,44)$ as it was revealed by the correlation analysis.

Management of emotions reflects the individual's ability to estimate and control the extent of external psycho-traumatic factors impact on his emotional state (ability to protect himself from negative emotions). The level of ability to manage emotions in the control group was $69 \%$ in the course of acmeology based continuous professional training of physical education specialists, which was only $7,45 \%$ more than in the control group $(61,55 \%)$.

Thus, the level of personality's acme-traits development as a component of the physical education specialists' acmeological competence in the process of continuous acmeology based professional training on the all levels of higher education was $73,9 \%$. In the control group of students this indicator was $54,68 \%$, that was $19,22 \%$ less than the experimental group.

Analyzing the level of personality's acme-traits development as a component of the physical education specialists' acmeological competence in 
the process of continuous acmeology based vocational training we revealed that in the experimental group of students it was $73,9 \%$ in general. The level of this component development in the control group was 54,68\%, which was $19,22 \%$ less than the experimental group.

Analysis of the results obtained after the pedagogical experiment indicates that the experimental group students achieved statistically significant differet level of both the level of acmeological competence as a whole development, and in levels its components development $(p<0,05)$. There was a certain dynamics for students of the control group, but there were no statistically significant differences neither in the level of acmeological competence development nor in its studied components $(\mathrm{p}>0,05)$.

In order to improve the quality of physical education specialists' professional training, as a result of correlation analysis, we determined the relations and interinfluence of acme-motivational, cognitive-acmeological, acmeological-activity components and personality's acme-traits on the level of acmeological competence development. The analysis of the dynamics of physical education students' acmeological competence development is given in Table 1.

Table 1

\section{Dynamics of levels of acmeological competence development for the physical education specialty students}

\begin{tabular}{|c|c|c|c|c|c|c|c|c|c|}
\hline \multirow[b]{2}{*}{ № } & \multirow[b]{2}{*}{ Indicators } & \multicolumn{4}{|c|}{ Control group, \% } & \multicolumn{4}{|c|}{ Experimental group, \% } \\
\hline & & 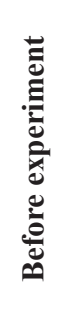 & 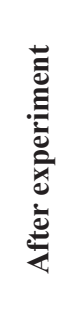 & 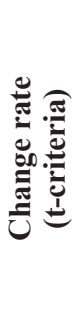 & 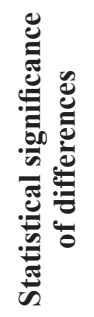 & 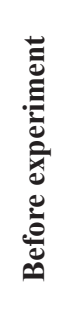 & 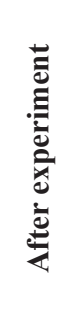 & 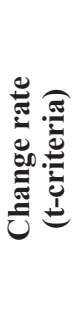 & 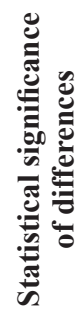 \\
\hline 1 & Acmeological competence & 51,5 & 62,25 & 10,25 & $\mathrm{p}>0,05$ & 51,3 & 78,69 & 27,39 & $\mathrm{p}<0,05$ \\
\hline 2 & $\begin{array}{l}\text { Acme-motivational } \\
\text { component }\end{array}$ & 54,6 & 63,3 & 8,7 & $\mathrm{p}>0,05$ & 55,2 & 84,3 & 29,1 & $\mathrm{p}<0,01$ \\
\hline 3 & $\begin{array}{l}\text { Cognitive-acmeological } \\
\text { component }\end{array}$ & 65,8 & 75,4 & 9,6 & $\mathrm{p}>0,05$ & 65,4 & 88,0 & 22,6 & $\mathrm{p}<0,05$ \\
\hline 4 & $\begin{array}{l}\text { Acmeological activity } \\
\text { component }\end{array}$ & 49,6 & 55,6 & 6,0 & $\mathrm{p}>0,05$ & 50,3 & 68,54 & 18,24 & $\mathrm{p}<0,05$ \\
\hline 5 & Personality's acme-traits & 43,5 & 54,68 & 11,18 & $\mathrm{p}>0,05$ & 44,3 & 73,9 & 29,6 & $\mathrm{p}<0,01$ \\
\hline
\end{tabular}


A high correlation of the level of acmeological competence development can be observed with the acmeological activity component $(\mathrm{r}=0,81)$, acme-motivational $(\mathrm{r}=0,78)$ and cognitive-acmeological $(\mathrm{r}=0,71)$. We found a significant correlation of the level of acmeological competence development with personality's acme-traits $(r=0,5)$.

To verify the author's concept of physical education specialists'continuous professional training based on the acmeology principles we used a factor analysis. As a result of factor analysis, the interconnections of the acmeological competence components indicators were proved experimentally: acme-motivation, cognitive-acmeological, acmeological-activity, personality's acme-traits (acme-motivational and personal, personal and professional, emotional and psychological, cognitive-acmeological and research).

\section{Discussion of the study results}

As a result of the study of the physical education specialists' personality's acme-traits peculiarities development in the process of acmeologically based continuous training we added a data to the study done by N. V. Kuzmina. The concept of "acmeological competence of physical education specialists" is defined, which is understood as the integrated ability of the individual. It could be developed in the process of continuous acmeologically based vocational training, and reflects the ability of a specialist to build his own self-development with constant complication of tasks and increasing the level of achievements for training, self-development and self-improvement throughout life, achievement of personal and professional acme.

We have theoretically substantiated the components of the acmeological competence of the physical education specialists (such as acme-motivational, cognitive-acmeological, acmeological-activity, personality's acmetraits), which confirms the data of Y. V. Andriyenko about the importance of personality's acme-traits as a component of acmeological competence. According to our research, the list of personality's acme-traits of the physical education specialists was added by following: desire for self-education, love for children, reasonable demands, sense of measure, pedagogical cycle, personal example, ability to control their activities and behavior, observation, ingenuity, ability to use voice, facial expressions, gesture and pedagogical intuition. As before there were personality's acme-traits proposed by B. Mitzkan, T. Zavgorodna, A. Shpilchak, G. Preszta, I. Vipasnyak, 
B. Lisovsky, the following as following: creative potential (creativity), communicative abilities, organizational skills, the need of achievements, the attitude to himself ("Self-concept"), the ability to psychological proximity to other person, a sense of civic duty, empathy, the ability to recognize the emotions of others, emotional awareness and emotion management.

There were data obtained by V. D. Gladkov, A. O. Derkach confirmed concerning the acmeological invariants of professionalism as the basic traits of the specialist personality that ensure the efficiency and stability of future professional activity.

For the first time there was determined the total percentage of dispersion, which indicates the importance of acmeological competence components, which involves the development of physical education specialists' personality's acme-traits as its components: acme-motivational and personal components, personal and professional emotional and psychological. Also, for the first time, we determined the strength of correlation influence of acme-traits as a component of physical education specialists' acmeological competence: a high correlation relationship was for creative potential (creativity), communicative abilities, organizational skills, the need to achievements, the attitude towards himself ("Self-concept"), the ability to psychological proximity to other person; significant correlation was between such personality's acme-traits as a sense of civic duty, empathy, ability to recognize the emotions of others, emotional awareness; moderate bond was between personality's acme-traits and emotions control as a result of correlation analysis.

\section{Conclusions}

Thus, we have established that the formation of personality's acme-traits as a component of physical education specialists' acmeological competence occurs unevenly during studying in a higher educational institution, and its indices have a different effect on the final level of their formation. The following conclusions were made in accordance to the study results:

1. The level of development of personality's acme-traits as a component of the physical education specialists' acmeological competence for the experimental group of students in the process of continuous acmeology based vocational training at all levels of higher education was $73,9 \%$. In the control group of physical education students this indicator was $54,68 \%$, which was 19,22\% less than for the experimental group. 
2. The general percentage of dispersion was determined, which indicated the importance of following acmeological competence components: acme-motivational and personal components had a general percentage of dispersion of $43,53 \%$, personal and professional $-17,6 \%$, emotional and psychological - 10,3\%, cognitive-acmeological and research - 8,4\%. Specialists' personality's acme-traits are elements of these components.

3. As a result of the correlation analysis, we determined the strength of correlation influence of acme-traits as a component of physical education specialists' acmeological competence. We grouped the personality's acmetraits by the power of the correlation relationship: the high correlation with the level of the development of personality's acme-traits had creative potential (creativity) $(\mathrm{r}=0,91)$ of students and communicative abilities $(\mathrm{r}=0,91)$, as well as organizational ability $(\mathrm{r}=0,89)$, the need of achievements $(\mathrm{r}=0,76)$, the attitude towards himself ("Self-concept") $(\mathrm{r}=0,74)$ and the ability to psychological proximity to other person $(r=0,74)$. A significant correlation with the level of development of personality's acme-traits had a sense of civic duty $(r=0,65)$, empathy $(r=0,64)$, ability to recognize emotions of other people $(r=0,6)$ and emotional awareness $(r=0,53)$. Moderate interinfluence on the level of formation of physical education specialists' acmeological competence had personality's acme-trait as control of emotions $(r=0,44)$.

However, the study of the formation of personality's acme-traits of physical education specialists in the process of acmeologically based continuous professional training does not exhaust the entire problem. The further promising areas of research could be the application of the acmeological approach to the training of physical education specialists at the $\mathrm{PhD}$ level.

\section{References:}

1. Andrienko E. V. (2010) Antropologicheskij podhod k problemam obrazovanija [Anthropological approach to the problems of education]. [Jelektronnyj resurs] Idei i idealy, no.1 (3), vol. 2, pp. 2-10.

2. Antonova O. Ye. (2008) Teoretyko-metodolohichni zasady navchannya obdarovanyx studentiv u pedahohichnyx universytetax [Theoretical and methodological principles of teaching gifted students in pedagogical universities] $(\mathrm{PhD}$ Thesis), Kyiv, NAPN Ukrayiny; In-t ped. osvity i osvity doroslyx.

3. Hladkova V. M. (2014) Akmeolohichni zasady profesijnoho samovdoskonalennya menedzheriv vyshhyx navchalnyx zakladiv [Acmeological principles of professional self-improvement of managers of higher educational establishments] (PhD Thesis), Kyiv, NAPN Ukrayiny, Un-t menedzh. osvity. 
4. Dereka T. (2016) Pedahohichna teoriya pro problemy neperervnoyi profesijnoyi pidhotovky faxivciv fizychnoho vyxovannya [Pedagogical theory about problems of continuous professional training of specialists in physical education]. Molodyj vchenyj, no. 10, pp. 62-69.

5. Dereka T. H. (2015) Formuvannya akmeolohichnoyi kompetentnosti faxivciv fizychnoho vyxovannya $\mathrm{v}$ procesi neperervnoyi profesijnoyi osvity [Formation of acmeological competence of specialists in physical education in the process of continuous vocational education]. Naukovyj Visnyk Donbasu, no. 12, pp. 54-62.

6. Derkach A. A. (2004) Akmeologicheskie osnovy razvitija professionalizma [Acmeological foundations for the development of professionalism]. Moscow: Voronezh. (in Russian)

7. Kuz'mina N. V. (2015) Fundamental'naja akmeologija kak vazhnejshij resurs processa povyshenija produktivnosti obrazovanija [Fundamental acmeology as the most important resource of the process of increasing the productivity of education]. Problemi osviti: zbirnik naukovih prac', no. 84, pp. 14-20.

8. Nachinskaja S. V. (2005) Sportivnaja metrologija [Sports Metrology]: uchebnoe posobie dlja studentov vysshih uchebnyh zavedenij. Moscow: Akademija. (in Russian)

9. Priorytety ta perspektyvy akmeolohichnoho zrostannya vchytelya fizychnoyi kul"tury v umovax modul"noho navchannya (2012) [Priorities and perspectives of the acmeological growth of the teacher of physical culture in conditions of modular training]. Myckan B., Zavhorodnya T., Shpyl"chak A., Prezlyata H., Vypasnyak I., Lisovs"kyj B. Fizychne vyxovannya, sport i kul "tura zdorov'ya u suchasnomu suspil"stvi: zbirnyk naukovyx prac", no. 4 (20), pp. 91-97.

10. Dereka T. (2016) The building personal component in the structure of physical education specialists' acmeological competence. The advanced science journal, no. 2, pp. 59-62.

11. Dyba T. (2015) Professional training of specialists of physical training on the competence base. The advanced science journal, no. 5, pp. 99-102. 